\title{
2021 Handbook of Florida Water Regulation: Florida Air and Water Pollution Control Act ${ }^{1}$
}

\author{
Michael T. Olexa, Tatiana Borisova, and Jana Caracciolo²
}

\section{Preface}

This handbook is designed to provide an accurate, current, and authoritative summary of the principal federal and state (Florida) laws that directly or indirectly relate to agriculture. This handbook provides a basic overview of the many rights and responsibilities that farmers and farmland owners have under both federal and state laws as well as the appropriate contact information to obtain more detailed information. However, the reader should be aware that because the laws, administrative rulings, and court decisions on which this handbook is based are subject to constant revision, portions of this publication could become outdated at any time. Several details of cited laws are also left out due to space limitations. This handbook is provided as an educational text for those interested in water use and water resource issues in Florida.

This handbook is distributed with the understanding that the authors are not engaged in rendering legal or other professional advice, and the information contained herein should not be regarded as a substitute for professional advice. This handbook is not all inclusive in providing information to achieve compliance with the federal and state laws and regulations governing water protection. For these reasons, the use of these materials by any person constitutes an agreement to hold harmless the authors, the UF/IFAS Center for Agricultural and Natural Resource Law, and UF/IFAS Extension for any liability claims, damages, or expenses that may be incurred by any person as a result of reference to or reliance on the information contained in this handbook. Note: UF/IFAS is the acronym for University of Florida, Institute of Food and Agricultural Sciences.

\section{FAWPCA Overview}

The Florida Legislature enacted the Florida Air and Water Pollution Control Act (FAWPCA) in 1967, in recognition that pollution of Florida's air and water is a menace to public health and welfare; is harmful to wildlife; and impairs domestic, agricultural, industrial, and other uses of air and water. Since 1967, FAWPCA has been modified to reflect changing federal and state policies and rules, as well as changing environmental protection needs in Florida.

The purposes of FAWPCA are twofold:

- to conserve, protect, and improve the quality of Florida's waters for a variety of purposes, including public water supplies and preservation of wildlife

- to achieve and maintain levels of air quality that will protect human health and safety, plant and animal life, and property in order to promote the social and economic development of Florida

1. This document is FE607, one of a series of the Food and Resource Economics Department, UF/IFAS Extension. Original publication date October 1998. Revised June 2017 and April 2021. Visit the EDIS website at https://edis.ifas.ufl.edu for the currently supported version of this publication.

2. Michael T. Olexa, professor, Food and Resource Economics Department, and director, UF/IFAS Center for Agricultural and Natural Resource Law; Tatiana Borisova, associate professor, Food and Resource Economics Department; and Jana Caracciolo, student, Levin College of Law; UF/IFAS Extension, Gainesville, FL 32611.

The Institute of Food and Agricultural Sciences (IFAS) is an Equal Opportunity Institution authorized to provide research, educational information and other services

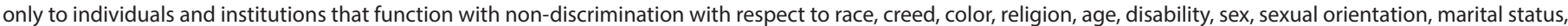

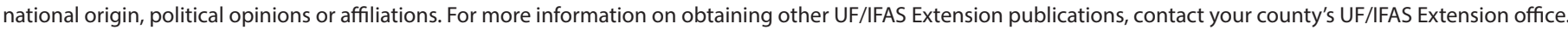
U.S. Department of Agriculture, UF/IFAS Extension Service, University of Florida, IFAS, Florida A \& M University Cooperative Extension Program, and Boards of County Commissioners Cooperating. Nick T. Place, dean for UF/IFAS Extension. 


\section{What is the Water and Air Quality Regulation Framework under FAWPCA?}

FAWPCA establishes the general framework for water and air quality regulations in Florida. It provides the Florida Department of Environmental Protection (FDEP) with broad powers and duties to accomplish the statutory goal of protecting and improving water quality throughout the state. Under FAWPCA, FDEP must:

- Adopt a comprehensive program for the prevention, abatement, and control of pollution of the air and waters of Florida, and review and modify this program as necessary

- Develop and approve plans to provide for air and water quality control and pollution abatement

- Exercise general supervision of the administration and enforcement of the laws, rules, and regulations related to air and water pollution in Florida

To protect drinking water sources, FDEP must:

- Analyze the existing and potential drinking water resources of the state to ensure they remain free from harmful quantities of contaminants

- Compile, correlate, and disseminate available information on any contaminant which endangers or may endanger existing or potential drinking water resources

FAWPCA requires FDEP to establish water resource and air quality standards, and monitor the air and water resources. Specifically, FDEP must:

- Classify Florida waters based on the waters' designated uses. The following are the current water use classifications:

- Class I-potable water supplies

- Class II-Shellfish Propagation or Harvesting

- Class III-fish consumption, recreation, propagation and maintenance of a healthy, well-balanced population of fish and wildlife

- Class IV-Agricultural Water Supplies

- Class V-Navigation, Utility, and Industrial use.

- Establish rules that provide for Outstanding Florida Waters, a special category of water bodies within the state, which are worthy of special protection because of their natural attributes
- Take and test samples of air and water to determine the levels of air and water quality throughout Florida; FDEP is also authorized to determine the source of pollution if a sample collected is below air or water quality standards

- Establish a groundwater quality monitoring network designed to detect or predict contamination of the groundwater resources of the state

For more information on water quality standards in Florida, see: http://edis.ifas.ufl.edu/topic_water_quality

\section{If FDEP determines water resources in an area are} impaired, that is, not meeting relevant water quality standards, FDEP must coordinate the development of a plan to limit pollution loadings (referred to as total maximum daily loads plan) through existing water quality protection programs. To achieve the goals of the total maximum daily load plan for a water body, the department may lead the development of a Basin Management Action Plan (BMAP).

Stormwater management is very important for protection of the quality of water resources in Florida, and FDEP must coordinate Florida's stormwater program.

FDEP can use a variety of policy and management tools to address or prevent pollution problems, including permits, incentive programs, land acquisition, or voluntary cooperation mechanisms. Specifically, according to FAWPCA, FDEP must:

- Implement programs to protect and restore Florida's water, including the implementation of land acquisition programs

- Establish a permit requirement system for the operation, construction, or expansion of any installation that may be the source of air or water pollution, and provide for the issuance and revocation of such permits

- Promote voluntary cooperation by persons or groups to protect air or water quality

- Establish and administer incentive programs related to pollution reduction

For consulting, research and outreach programs, FDEP is required to:

- Encourage studies, investigations, and research related to pollution and its causes, effects, prevention, abatement, and control

- Collect and disseminate information and conduct outreach activities related to water and air pollution 
- Consult with any person proposing to construct, install, or otherwise acquire a pollution control device or system concerning the effectiveness of such device or system, or the pollution problem related to the source, device, or system

\section{FAWPCA alsolinks federal and state water and air} protection laws and regulations. Specifically, according to FAWPCA, FDEP must:

- Exercise the duties, powers, and responsibilities required of the state under the federal Clean Air Act and Clean Water Act (CWA). (For more information on the CWA, see FE582-Clean Water Act)

- Adopt the rules and requirements related to administration of the Federal National Pollution Discharge Elimination System (NPDES) permitting program in Florida (Note that NPDES permits are required for industrial, municipal, and some agricultural pollution sources that discharge pollution into surface waters)

\section{Who enforces FAWPCA?}

FDEP is the primary enforcer of FAWPCA and is responsible for developing its rules and laws. FAWPCA provides FDEP with judicial and administrative remedies. FDEP may institute a civil action in a court of competent jurisdiction or an administrative proceeding to establish liability and to recover damages for any injury to the air, waters, or property, including animal, plant, and aquatic life, of the state caused by any violation.

For a complete list of the duties, powers, and requirements of FDEP under FAWPCA, contact FDEP.

\section{What are the penalties under FAWPCA?}

Any person who causes pollution that harms or injures human health or welfare, animal, plant, or aquatic life or fails to obtain a required permit under FAWPCA is liable for the damage caused and subject to a civil penalty for each offense in an amount of not more than $\$ 15,000$ per offense.

Any person who willfully causes pollution that harms or injures human health or welfare, animal, plant, or aquatic life is guilty of a felony of the third degree and subject to a fine of not more than $\$ 50,000$ or by imprisonment for 5 years, or by both, for each offense.

Any person who due to reckless indifference or gross careless disregard causes pollution that harms or injures human health or welfare, animal, plant, or aquatic life is guilty of a misdemeanor of the second degree and subject to a fine of not more than $\$ 10,000$ or by 60 days in jail, or by both, for each offense.

\section{Sources}

Chapter 403, Florida Statutes, Sections 403.011 to 403.0611

Chapter 62-302, Florida Administrative Code (Designated uses and surface water quality standards)

\section{Acknowledgments}

The authors are indebted to the personnel of both state and federal agencies who provided their time and advice in the preparation of this handbook. We acknowledge Carol Fountain and Susan Gildersleeve at the University of Florida for their assistance in editing this handbook. We also acknowledge funding received for updating this publication from the James S. and Dorothy F. Wershow Agricultural Law Endowment. 